In the thigh piece were four slots, two on either side, sixteen inches apart on the outer side, and ten inches apart on the inner side, and two straight splints, one for the outer side to extend the whole length of the thigh piece, and one for the inner side to reach from just below the perineum to the knee. These were each four inches wide, and each provided with iron bolts with screw ends, to work in the slots, so that they might be moved backwards and forwards towards the middle line, so as to fix the thigh when it was brought into position. These bolts were to be secured nnderneath by winged nuts. In the lower portion of the inclined plane was a foot piece, moving in a slot longitudinally; this was fixed by a nut underneath, which held it perpendicularly as regards the plane. There were also two triangular pieces cut out of the board, leaving a piece in the middle the shape of the leg from two inches below the knee to where the heel would be when the leg was in position. To apply the apparatus, which was done on Feb. 20th, I removed the splints from the thigh piece, padded it, and slipped it under the limb. The femur was then brought into position, and held there whilst I applied the side splints and fixed them. I then put on a straight splint over the top of the thigh, to prevent any upward displacement and bandaged all together. The next thing was to fix the foot to the foot piece; this was done and traction put on the leg till the fracture was reduced and the foot piece was then fixed, and the ankle and leg up to just Below the wound were firmly bandaged to the apparatus. The dressings were then applied to the wounds and the limb lefo undisturbed, except that from time to time the side splints were tightened and the top splint removed to allow of inspection of the fractures - March 23rd : Removed apparatus, and gave a stimulating liniment to $\mathrm{rub}$ the thigh and knee. -25th: Began slight passive movement of knee.-A pril 6th: Encased thigh in plaster-of-Paris._-10th: Patient was able to move about the house with crutches and left foot in a aling. Large wound almost healed.-May 18th: Removed plaster-of-Paris case.

The patient is now able to walk long distances with only a stick for support. His injured leg is not quite an inch shorter than the other, although several small pieces of necrosed bone have come away from the tibia, and there is still more to come. There is remarkably little necrosis considering the comminution at the seat of fracture. The patient is a man of twenty-four years of age, and of splendid physique. The width of the splint and the position in which the foot piece can be fixed upon it, 1 olaim, has prevented the possibility of any eversion of the foot, and the two triangular spaces on either side of the leg allow of the application of dressings \&c. with no pain to the patient or risk of disturbing the fractures. The side splints at the thigh effectually prevent any sideways displacement, and, if combined with a splint at the top, close the limb, as it were, in a box, and prevent any movement of the bone in any direction. Another advantage is that they are easy to tighten or remove. Their removal can be sccomplished without any movement of the limb.

South Moor, near Chester-le-Street.

\section{Climital atente:}

\section{MEDICAL, SURGICAL, OBSTETRICAL, AND THERAPEUTICAL.}

\section{NOTE ON THE EFFECTS OF INFLUENZA UPON} THE MIDDLE EAR.

By Sir William Dalby, F.R.C.S.,

CONSULTING AURAL SURGEON TO ST. GEORGE'S HOSPITAL.

AMongst the various ultetior effects which the influenza has left upon its subjects it might have been expected that the tract of mucous membrane which lines the middle ear would have been included with tolerable frequency; and although this has in a measure proved to be true, it has pccurred in a manner some what different from what might have been anticipated. It is true that a certain number of persons during the high temperature stage have for the first sime in their lives been attacked with acute inflammation of the middle ear, ending in a few hours with perforation of the tympanic membrane, but these cases, so far as my experience goes, have been comparatively rare; equally rare, it seems to me, have been cases in which persons with ears that have always been healthy have become affected with non.purulent catarrh of the middle ear, combined with obstruction of the Eustachian tubes. I have (in common no doubt with other surgeons) been called to some cases where rapid and acute inflammation of the middle ear has taken place, and to some in which septicæmia has shortly followed, but such instances form 8 very small proportion to the considerable numbers whom I have observed to be affected in a different manner. These have been confined chiefly to those persons who are and have been for many years the subjects of perforations. There are a good many people who, having perforations, have learned under treatment so successfully to manage them by the use of an absorbent cotton pad that they hear tairly well, and have so minute a quantity of discharge as to be barely noticeable, and in this way continue for many years in a very comfort. able condition in respect of hearing and local inconvenience. Many of this class, after an attack of influenza, come back again complaining of further loss in hearing power atd greatly increased discharge, which has proved intractable to ordinary measures. The pads have ceased to have their accustomed effect on the hearing for the whole day, and now, in consequence partly of getting soaked with discharge, they are useless. But beyond this the congested condition of the tympanic cavity of itself dulls the hearing so much that the ordinary results of pressure on the stapes are gone for the time. Again, there are many subjects of perforations in whom the cavity of the tympanum has ceased to secrete purulent matter, a condition of a perforation which may be described as dry, and which of ten remains so for many years. I have observed many of these to resume their previous activity in regard to discharge after an attack of influenza, although for long periods, notwithstanding ordi. nary colds and exposure to all snrts of variations in climate, they have continued healthy. Thus a person with healthy ears has little to dread from influenza so far as this mucous surface is concerned, but it may become a serious trouble to one whose ears have formerly been the seat of inflammation. Savile-row, $\mathrm{w}$.

\section{CASE OF HEPATIC ABSCESS.}

BY JoHN MCMUN,, L.R.C.S.I., \&c.

A SOLDIER, aged thirty - three, of moderate drinking habits, had served six years in the army, two of them in Bengal. He had ague in 1888. While coming through Suez early in November, 1890, his appetite failed. He arrived at Aldershot on the 19 th of the same month. Then his eyes looked yellow and his urine was high coloured. On Dec. lst he became impatient at the hospital, but was discharged in a week. At the time of his discharge he complained of epigastric pain. There was no history of sweats or rigors. When I saw the patient on Jan. 2nd, 1891, he weighed $8 \frac{1}{2}$ st., his height being $5 \mathrm{ft} .5 \frac{1}{2}$ in. He was worn-looking, anæmic, and slightly jaundiced, with weak pulse, normal temperature, clean tongue, regular bowels, and slight cough. The urine was strongly acid, sp. gr. 1020, clear, plentiful, fragrant, and free from sugar and albumen. He complained of his stomach. There was an epigastric tumour, solid, firm, smooth, rounded, fixed, visible, in diameter three inches, slightly tender, and scarcely moving with respiration. Treatment: quinine, nitro-muriatic acid, and rest. Jan. 10th : Temperature (2 P.M.) $99^{\circ}$; pulse $96,-186 \mathrm{~h}$ : Doubtful deep fluctuation.-21st: Temperature (2 P.M.) $97 \cdot 8^{\circ}$; pulse $96 .-22$ nd : Temperature (2 P.M.) $97 \cdot 8^{\circ}$; pulse 96 . The tumour was explored with a needle and afterwards freely opened. Four ounces of thick chocolate-coloured pus escaped. A drainage-tube'was inserted, and the whole covered with linseed poultice moistened with carbolic oil. Temperature $(6$ P.M. $) 101^{\circ}$; at 9 P.M. it was normal.23rd: Sweated a little last night. -26th : Evening tem. perature 101\%. Headache.-27 th: Evening temperature $100 \cdot 5^{\circ}$ - $28 \mathrm{th}$ : Abundant discharge, which seems to come from a superficial cavity, with an upward inclination from opening. A painful and tender cord runs from the edge of the liver to the umbilicus.-Feb. 3rd: Dis charge not so free. -5 th: Temperature (6 P.M.) $99^{\circ}$. Headache. Patient not so well.-8th: Tumour, which had gradually shrunk, more prominent, coincidently with decreasing 
Hischarge; evening temperature normal. A probewas allowed to ferret its way through softened tissue for about two inches backwards, suddenly it dropped into a large cavity, and pus welled up in abundance, the passage was enlarged with dressing forceps, and this second cavity drained and dressed with carbolic oil. $-18 \mathrm{oh}$ : Since last date syringed through drainage tube with Condy's fluid; tube expelled from a shallow dimpled recess representing the wound.24th : Patient joined regiment October, 1891, in the best of health.

The total amountof matter expelled was about three pints. Gloucester.road, N.W.

\section{NOMA AS A COMPLICATION OF ENTERIC FEVER.} By John Donald, M.A., M.B.

As nome is a rare complication of this disease, a fow remarks on two cases in which ib occurred may prove interesting,

0n Sepo. 9th, 1891, I began to attead two children, Lizzie $\mathrm{P}_{-}$, aged four, and Jane $\mathrm{B} \longrightarrow$, aged eight, both of whom were found to be suffering from enteric fever. They had been ailing for about a week, Lizzie 3 - having been taken ill a day or two before her sister. The symptioms all through were much alike in the two cases, the nervous symptoms predominating. There was marked prostration, and great restlessness and delirium of a low type. The temperature varied from $102.5^{\circ}$ to $104^{\circ}$, and the pulse ranged from 110 to 130 . Diarrhca was present in both, bao persisted longer, and was with difficulty controlled in the elder. No rash could be found in either case, and there were no lung complications. The tongue was dry and cracked, and there were abundant sordes on the lips and teeth. About Sept. 13th the pulse became very weak, and there was a tendency to heart failure. This was combated with stimulants, given freely in the form of diluted brandy; but it was with difficulty that they were roused from their lethargic condition to partake of this and other necessary nourshiment. With the persistence of such a low "typhoid" state, the prognosis was very bad, and when noma set in their recovery was practically hopeless. On Sept. $16 \mathrm{th}$ a hard swelling was felt in the right cheek of the younger, which gradually increased in size and got tense and glazed externally. Ulceration took place internally, but the disease did not follow the rapid course that sometimes occurs. The child remained in a comatose condition till Sept. $20 \mathrm{tb}$, when she died, before perforation of the cheek had taken place. On Sapt. 18th noma was found in the right cheek of the elder girl, and pursued a similar course, till she died, in the same comstose condition, on Sept. $22 n d$.

Noma as a rule follows on some debilitating disease, but for its development the presence of foul air and bad sanitary arrangements are usually regarded as essential. Here the conditions were present, as the cases occurred in a small, badly ventilated house in a narrow street. In another case, which I saw during convalescence from measles, where a fatal issue likewise took place, the house was permeated with bad smells. It is probable that the microorganisms supposed to canse this disease gain entrance to the tissues lorally, as it is difficult to conceive how they should select such a site, if they were introduced into the circulation in the first place. In the cases of enteric fever referred to it is easy to comprehend that the state of the mucous membrane of the mouth was such as to furnish a suitable spot for the inroad of disease germs. In regard to local treatment, no violent measures were resorted to, as the low, practically hopeless condition of the patients did not seem to warrant any such. So much of the ulcerated tissue as could be scraped easily away was removed, and antiseptic washes were freely employed to cleanse the mouth. Glasgow.

AN UNUSUAL CASE OF TWINS.

By GEORGE JoInN O'REILIY, L.K.Q.C.P.I., \&c.

I ATTENDED Mis. $\mathrm{K}$ - on the 8 th ult. in her fourth confinement. There was nothing unusual to note in the history of this pregnarcy, except that she complained of not having felt the movements of the child for some ten days before delivery. During the labour I felt satisfied that I noticed the movements of the foetus during examination. When delivery was effected an eight months' embryo presented itself in a macerated condition, the cuticle peeling of in several places. When I grasped the uterus to express the placenta I noticed that organ was larger than usual after delivery, and that the surface was lumpy and uneven. I examined per vaginam, but could noo detect anything abnormal. I gave a dose of ergot and waited results. Labour pains soon set in, and became stronger every minute, and on again examining I found the head of a second foetus presenting. After a short time a living child was expelled, and as it was very feeble I had it wrapped in cotton wool, and kept near the fire. The placenta came away within a short time. There was little or no bremorrhage. The case terminated normally. The mother made a good recovery and was up on the eleventh day, I hardly expected the child to live, and did not weigh it at birth. However, the infant has lived, and takes its nourishment well, and seems to thrive. On the twentyfirst day it weighed with cotton wool and shawl $3 \mathrm{lb} .1 \mathrm{oz}$ A week afterwards it wejghed $3 \mathrm{lb} .50 \mathrm{z}$. There was only one placenta; the cords of both were attached within a short distance of each other ; two-thirds of the placenta were of a livid red colour and of firm consistence, and to this portion the firstborn was attached. The cord was three times as thick as that of the living child, the other one-third portion of placenta was healthy. There was a distinct line of demareation between the two portions. The stillborn child was unfortunately not weighed, but $I$ should say it was from 4 to $51 b$.

Highgate, $N$.

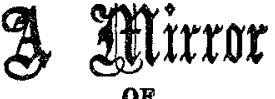

\section{HOS P T A L P ACTICE, BRITISH AND FOREIGN.}

Nulla autem est alia pro certo noscendi via, nisi quamplurimas eb mor. borum et dissectionum historias, tum aliorum tum proprias collectas habere, et inter se comparare.-MORGAGNI De Sed. et Cous. Morb. aabere, et inter se

\section{SEAMEN'S HOSPITAL, GREENWICH.}

NOTES OF TWO FATAL CASES OF INFLUENZA.

(Under the care of Dr. JOHN ANDERSON, C.I.E.)

THESE two cases are specially interesting, as showing the mode of death in cases of influenza, which are not fatal in consequence of bronchitis, pneumonia, or some other similar complications. Both patients died from syncope due to cardiac failure induced by the influenza alone, and in both no cardiac lesion, either of the walls or of the valves, existed. In the second case the histological examination, showing that the heart structure was quite normal, was made by Mr. Hewlett, M.B. Lond., Demonstrator of Bacteriology in King's College. For the report of these cases we are indebted to Dr. M. H. Spencer.

CASE 1.-A. C—, a sailor, aged thirty.five, was admitted into the hospital on Jan. 11th, 1892. He was taken ill eleven days before admission with pains "all over him," accompanied by some cough, but had not kept his bed. When he was admitted the temperature was $101^{\circ} 6^{\circ}$; respiration 42 ; pulse 118. Auscultation revealed only sibilant rhonchns over the greater part of the lungs, with sorre small râles, most marked over the left lower lobe. No impairment of resonance anywhere over the lungs. The heart sounds were normal. The urine was free from albumen. There was a good deal of cough, with profuse watery expectoration. Ammonia mixture ordered every two hours. For the next two days the patient remained in much the same condition, the temperature still continuing high, ranging between $102 \cdot 4^{\circ}$ and $103.4^{\circ}$ at night, and falling to between $99^{\circ}$ and $100^{\circ}$ in the morning. The dyspncez, however, had diminished. At midnight on Jan. 14th the pulse for the first time showed signs of failure. Stimulant was freely given, and quinine and digitalis were ordered. On the 15 th his condition was much worse. The pulse was 140 , and although the bronchial signs over the lungs had diminished 